\title{
Topical PVDF/Sirolimus
}

National Cancer Institute

\section{Source}

National Cancer Institute. Topical PVDF/Sirolimus. NCI Thesaurus. Code C88340.

A topical formulation consisting of a polyvinylidene fluoride (PVDF) polymer resin containing the macrolide sirolimus (rapamycin), produced by the organism Streptomyces hygroscopicus, with immunosuppressive activity. Upon application of topical PVDF/sirolimus, sirolimus migrates from the PVDF polymer resin into the skin. Once inside cells, sirolimus binds to the immunophilin FK binding protein-12 (FKBP-12) and forms a sirolimus:FKBP-12 complex. This complex binds to and inhibits the activity of the serine/threonine kinase mammalian target of rapamycin (mTOR), which may result in the suppression of cytokine-driven T-cell activation and proliferation. 